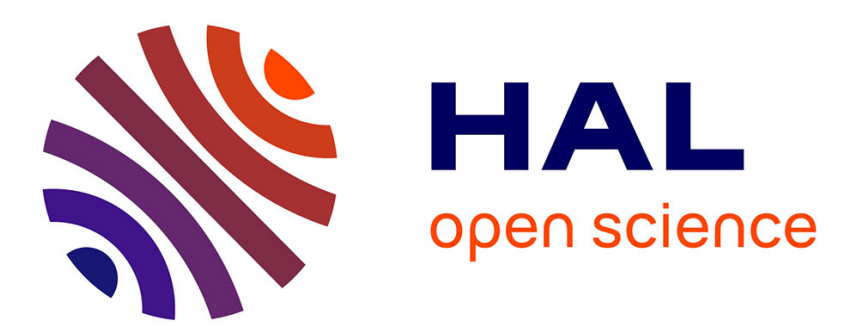

\title{
Evaluation of the social bond: a new method tested in Mus spicilegus
}

\author{
Julie Bardet, Daphné Kerhoas Essen, Christophe Féron, Patrick Gouat
}

\section{To cite this version:}

Julie Bardet, Daphné Kerhoas Essen, Christophe Féron, Patrick Gouat. Evaluation of the social bond: a new method tested in Mus spicilegus. Comptes Rendus Biologies, 2007, 330, pp.837-843. 10.1016/j.crvi.2007.08.006 . hal-00269394

\section{HAL Id: hal-00269394 https://hal.science/hal-00269394}

Submitted on 3 Apr 2008

HAL is a multi-disciplinary open access archive for the deposit and dissemination of scientific research documents, whether they are published or not. The documents may come from teaching and research institutions in France or abroad, or from public or private research centers.
L'archive ouverte pluridisciplinaire HAL, est destinée au dépôt et à la diffusion de documents scientifiques de niveau recherche, publiés ou non, émanant des établissements d'enseignement et de recherche français ou étrangers, des laboratoires publics ou privés. 
Ethologie

\title{
Evaluation of the social bond: a new method tested in Mus spicilegus.
}

\author{
Julie Bardet, Daphné Kerhoas Essen, Christophe Féron*, Patrick Gouat \\ Université Paris Nord, Laboratoire d'Ethologie Expérimentale et Comparée UMR CNRS 7143, \\ 99, avenue Jean-Baptiste Clément, 93430 Villetaneuse, France
}

*Corresponding author:

Tel. : (+33) (0)1 49403877

Fax. : (+33) (0)149403975

E-mail address: c.feron@1eec.univ-paris13.fr

\begin{abstract}
Innovative and fruitful studies of social bonds have been developed in recent years, although the methods used to establish the existence of a social bond between two individuals have not evolved significantly. Two types of paradigms have been currently used: the separation-reunion paradigm which evaluates the distress caused by the disruption of the social bond, and choice paradigms which test the specificity of the bond to a given individual. We have developed a new paradigm based on the idea that the cost an individual was ready to pay in order to gain access to a conspecific depended on the strength of the social bond between the two individuals. To test our paradigm we used moundbuilding mice, Mus spicilegus that present, in both males and females, a level of tolerance which differs greatly according to the degree of familiarity between the individuals. Our new method for testing social bond revealed unsuspected differences between males and females. Our results suggested that, at least in Mus spicilegus, strong social bonds were not necessary to the development of a high level of tolerance between individuals.
\end{abstract}

\section{Résumé}

L'étude du lien social a connu des développements importants ces dernières années, bien que les méthodes utilisées pour établir l'existence d'un lien social entre deux individus n'aient que peu évoluées. Traditionnellement, deux types de paradigmes sont utilisés : le paradigme de séparation- 
réunion qui évalue le stress causé par la rupture du lien social, et les paradigmes de choix qui testent la spécificité du lien envers un individu donné. Nous avons développé un nouveau paradigme basé sur l'idée que le coût qu'un individu était prêt à payer pour accéder à un congénère dépendait de la force $\mathrm{du}$ lien social entre les deux individus. Pour tester notre paradigme nous avons utilisé la souris glaneuse, Mus spicilegus qui présentethéorie de la demande du consommateur à la fois chez les mâles et les femelles, un niveau de tolérance qui diffère considérablement selon le degré de familiarité entre les individus. Notre nouvelle méthode pour tester le lien social a révélé des différences insoupçonnées entre les mâles et les femelles. Nos résultats suggèrent que, du moins chez Mus spicilegus, il n'est pas nécessaire que les individus entretiennent de forts liens sociaux pour que se développe un haut niveau de tolérance entre-eux.

Key-words: social bond, consumer demand theory, experimental test, Mus spicilegus.

Mots-clés : lien social, théorie de la demande du consommateur, test expérimental, Mus spicilegus.

\section{Introduction}

Social bonds play a fundamental role in mammal societies, modulating social relationships $[1,2]$ and consequently social organisation $[3,4]$. Recent developments in the study of the neurobiology of social attachment [5] have stimulated comparative studies and phylogenetic analyses [6-9]. Compared to the development of innovative and fruitful studies mentioned above, the methods used to establish the existence of a social bond between two individuals have not evolved significantly. Two types of paradigms have been currently used. The separation-reunion paradigm evaluates the distress caused by the disruption of the social bond. The distress is evaluated through physiological $[8,10,11]$ or behavioural responses [12-15] to separation and the return to baseline level after reunion. Both types of evaluations (i.e. physiological and behavioural responses) may be combined [16-18], but they do not always give the same results [19]. The problem here is to differentiate accurately the stress produced by the separation from a given individual, which reveals the existence of a social bond, from a non-specific reaction caused by the social isolation itself. In order to test the specificity of the bond to a given individual, choice paradigms have been developed. The subject must choose between two target individuals who differ in the degree of relationship to the subject $[20,21]$. To establish the 
preference, the times spent in proximity or in contact with each individual are compared. The problem is that a same result may be interpreted either as a true preference for a given individual suggesting a social bond, or as a repulsion for the less preferred individual. In other words, the time spent in the proximity of one of the target individuals is never really indivisible from the time spent near the other. Moreover, the interest for one of the target individuals may reflect a social bond or another social relationship such as aggressivity. Due to these various problems, some researchers have used both methods in a given study [22, 23], but the results have not always been congruent.

A paradigm based on the consumer demand theory has been developed in animal welfare studies to evaluate the importance of a resource $[24,25]$. Compared to choice tests, this paradigm gives information as to what is needed by animals, and not only as to their preferences. According to Broom [26], if an animal is making much effort to obtain a resource, the reasonable assumption is that this resource may improve its well being. In a study on the welfare of laboratory mice [27], Sherwin showed that mice were ready to pay the cost of gaining access to resources, even when the resource was an unfamiliar conspecific. The paradigm we have developed is based on the idea that the cost an individual was ready to pay in order to gain access to a conspecific depended on the strength of the social bond between the two individuals.

To test our paradigm we used mound-building mice, Mus spicilegus. These mice are known by the mounds they build to overcome the cold season. Although they are restricted to a limited area, a high level of tolerance is observed in over-wintering groups composed of familiar individuals of both sexes [28]. On the contrary, dyadic encounters between unfamiliar males and between unfamiliar females are very aggressive [29]. We used this difference in tolerance between familiar and non familiar individuals to test the validity of this method. Performance of familiar males or female pairs was compared to those of non familiar pairs. According to the experiment of Sherwin [27] on laboratory mice, a corridor of shallow water was the obstacle the subject needed to cross to join the target individual. Water is a natural element, existing in the habitat of mound-building mice and crossing did not need any learning period. 


\section{Material and Methods}

\subsection{Subjects and housing conditions}

Experimental animals were derived from a stock of 80 wild mound-building mice caught in Hungary in October 1999 and bred to the F6 generation under laboratory conditions $\left(20 \pm 1^{\circ} \mathrm{C}\right)$ with a $14: 10 \mathrm{~h}$ light:dark cycle. The mice were housed in standard polycarbonate cages $(26 \times 14 \mathrm{~cm}$ and $16 \mathrm{~cm}$ high) with sawdust (Special Diet Services, Witham, Essex, U.K.) and cotton wool was provided for nesting material. Food (type M20, Special Diet Services, Witham, Essex, U.K.) and water were supplied ad libitum.

Mice were weaned at 28 days of age and housed in same-sex sibling groups from 35 days of age. A total of 30 females and 30 males were used in these experiments. Males were $310.7 \pm 2.3$ days old and females $314.3 \pm 1.5$ days old at the time of the experiment.

At least three days prior to the experiment, animals were placed in same-sex sibling pairs in the experimental room. Mice were identified by hair clipping.

\subsection{Procedures}

The experimental device (figure 1) was composed of a starting box (26 x $19 \mathrm{~cm}$ and $9.7 \mathrm{~cm}$ high), and of another similar box, named thereafter ending box, which contained the target animal. The ending box was divided into two compartments by a partition with a one-way door so the target individual could not exit from its compartment. The two boxes were separated by a $40 \mathrm{~cm}$ long corridor which may be filled with water. To establish contact with the target individual, the subject must exit the starting box, cross the corridor, and enter the second box. A small hole $(0.1 \mathrm{~cm}$ in diameter $)$ was made in the one-way door so that the subject could smell inside the second compartment. Both male and female mound-building mice are able to identify the chemical signature of a conspecific [30-32]. To avoid mixing odours, mice were manipulated with gloves washed between each manipulation. The experimental device was in polycarbonate; between each experiment it was washed with dissolved Cleansinald (Johnson Diversey Company), and thereafter rinsed with clear water. 
Prior to testing each individual of a pair was isolated (from $1 \mathrm{~h}$ to $4.5 \mathrm{~h}$ ) in a clean cage provided with sawdust and cotton wool. Previous studies revealed that social isolation of animals originating from same-sex sibling groups promoted affiliative behaviour during reunion and that in both sexes no differences for separation periods lasting from one to four hours were observed (data not shown).

A test encompassed two successive stages: a familiarization stage (without water) and an experimental stage (with water). At the end of the isolation period, a polycarbonate shelter box with bedding material was placed in the cage of the target animal. When the target mouse was inside the shelter box, it was placed in its compartment of the ending box. The same procedure was used to transfer the subject to the starting box but the shelter box was maintained closed by a tap for a $10 \mathrm{~min}$ period. Then the tap was removed and the subject was free to explore the experimental device. The familiarization stage gave the subject the opportunity to discover that the target animal may be reached by crossing the corridor. The corridor was water-free and the subject had only to explore it to find the ending box. The familiarization stage ended when the subject reached the ending box and sniffed through the hole or after ten minutes after release whichever occurred first. During this stage the oneway door was maintained closed to avoid any confrontation with the target mouse which might have influenced the second stage of the test. At the end of the familiarization stage, the subject was closed in its shelter box until the corridor was filled with $1000 \mathrm{~cm}^{3}$ of warm water so that the mouse needed to swim in order to cross the corridor. The subject was then released and was free to move in the experimental device. This experimental phase lasted for a maximum of $10 \mathrm{~min}$ or ended when the subject reached the target mouse whichever occurred first.

For each sex, three groups of six subjects each were formed: in the familiar group (F) the subject and the target were from the same pair, in the non-familiar group (NF) the subject and the target mouse originated from different pairs; in the solitary group (S) no target animal was placed in the ending box. In the $\mathrm{F}$ and NF groups, one of the mice served as a subject and the other as a target individual. In the $\mathrm{S}$ group, mice were used only as subjects. Both animals of a given pair were used in only one experiment. In the NF group, combinations between the origin of the target and of the subject were never duplicated. 
Each experimental day, two subjects of each of the three experimental groups were tested. Female groups were tested during the first three days of experimentation; the male groups were tested during the next three days.

\subsection{Data analysis}

Three variables were measured from video recordings: the latency of the first entry inside the corridor, the latency of the first entry inside the ending box, the number of attempts before the first entry inside the corridor.

We considered an attempt to occur when a mouse passed the nose or the fore-body into the corridor and retreated without diving into the water.

Latency was measured from the releasing of the subject at the beginning of each phase. When the subject did not enter into a given part of the device, its score corresponded to the maximum duration of the phase.

Due to the size of the samples $(6<\mathrm{N}<18)$, we used non parametric tests with exact procedures [33]. Statistical analyses were performed on StatXact (Cytel Software Corporation, Cambridge, Ma, U.S.A.). Tests were two tailed; and data were expressed as mean $\pm \mathrm{SEM}$.

To test the relevance of the water as an obstacle, we compared the results between the familiarization and the experimental stages by using a permutation test for paired samples. This test gives the exact probability of a distribution as extreme or more extreme as the observed distribution. To compare the proportion of animals entering into the different parts of the device we used a test of $\square^{2}$.

To compare the different experimental groups we made a general analysis on the three groups using an ANOVA on general scores, followed by pair by pair comparisons using permutation tests for independent samples. We used the Bonferroni sequential procedure to correct for type I error due to repeated comparisons [34].

\subsection{Ethical note}

The experiments complied with the current laws of France (authorisation 93-0033 for CF; authorisation 93-006 for PG, Laboratory approval from the Prefecture of Seine Saint Denis, 
prefectorial decree 02-2651), and adhered to the Association for the Study of Animal Behaviour/Animal Behaviour Society Guidelines for the Use of Animals in Research.

\section{Results}

\subsection{Comparison between the familiarization and the experimental stages}

Most mice entered into the corridor when it was without water, only one female refused to exit the starting box before the end of the 10-min period. When the corridor was filled with water, the number of animals entering the corridor decreased significantly $\left(12 / 18\right.$ for males, $\chi^{2}=7.20, P=0.019 ; 10 / 18$ for females, $\chi^{2}=7.26, P=0.018$ ).

In males and females, latency to the first entry inside the corridor increased significantly when water was present (males: $80.2 \pm 15.6$ s without water and $295.2 \pm 57.4$ s with water, $P=0.0007$; females: $194.1 \pm 40.4 \mathrm{~s}$ without water and $394.5 \pm 50.9 \mathrm{~s}$ with water, $P=0.0093$ ). Whereas mice entered the corridor directly during the familiarization stage, they displayed numerous attempts before the first entry into the corridor whenever it was filled with water (males: $10.3 \pm 2.3$; females: $8.8 \pm 1.7 \mathrm{~s}, P<$ 0.0001 in both sexes). The mice that never entered into the corridor filled with water displayed more attempts than those entering the corridor (respectively for males: $22.0 \pm 2.5, \mathrm{~N}=6$ and $4.5 \pm 1.3, \mathrm{~N}=$ $12 ; P=0.0001$; respectively for females: $12.4 .0 \pm 2.7, \mathrm{~N}=8$ and $5.9 \pm 1.7, \mathrm{~N}=10 ; P=0.0578$ ).

Whether or not the corridor was filled with water mice of both sexes were able to cross the corridor in 1 to $4 \mathrm{~s}$. Nevertheless their behaviour after the first entry inside the corridor varied greatly. When no water was in the corridor, males explored the corridor and even returned to the starting box before they reached the ending box for the first time. When the corridor was filled with water, the males entering inside the corridor crossed the corridor directly and the difference between the latency of the first entry inside the corridor and the latency of first entry in the ending box decreased drastically (without water: $158.2 \pm 35.3 \mathrm{~s}, \mathrm{~N}=18$; with water: $10.7 \pm 7.0 \mathrm{~s}, \mathrm{~N}=12 ; P=0.0005, \mathrm{~N}=12$ ). In females, no significant difference was observed between the two phases (without water: $112.5 \pm 22.2 \mathrm{~s}, \mathrm{~N}=15$; with water: $120.6 \pm 53.4 \mathrm{~s}, \mathrm{~N}=9 ; P=0.5938, \mathrm{~N}=8$ ), and females tended to explore the corridor in a similar manner whatever the phase. 
As a result, the effect on the latency to the first entrance in the ending box was similar to the latency to the first entry inside the corridor although less pronounced (males: $283.3 \pm 40.7 \mathrm{~s}$ without water and $302.3 \pm 56.4$ s with water, $P=0.0222$; females: $314.1 \pm 39.8$ s without water and $451.2 \pm 44.9$ s with water, $P=0.0107$ ). For this reason the latency to the first entry inside the corridor was the only latency result presented in the comparisons between the experimental groups.

\subsection{Comparisons between the experimental groups}

\subsubsection{Males}

As shown in Figure 2, the three groups did not differ in their latency to enter into the corridor during the familiarization phase (ANOVA, $P=0.3033$ ). When water was present, the three groups differed significantly (ANOVA, $P=0.0179$ ). Latency was the shortest in the $\mathrm{S}$ group and longest in the NF group. The difference between these two groups was significant $(P=0.0216)$. The latency only tended to be shorter in the $\mathrm{F}$ group than in the NF group $(P=0.0671)$ and there was no significant difference between the $\mathrm{F}$ and $\mathrm{S}$ group $(P=0.4848)$.

The number of attempts before the first entry inside the corridor showed similar variations between the groups. It was maximum in the NF group $(19.0 \pm 4.0)$, minimum in the $\mathrm{S}$ group $(4.2 \pm 1.5)$, and intermediate in the $\mathrm{F}$ group $(7.8 \pm 3.4)$. The overall comparison was significant (ANOVA, $P=$ $0.0139)$, but only the difference between the NF and $\mathrm{S}$ groups reached significance $(P=0.0108)$.

\subsection{Females}

Contrary to males, groups differed in their latency to enter into the corridor during the familiarization phase (ANOVA, $P=0.0462$ ) (Figure 3). The pair by pair comparisons revealed a significant difference between the $\mathrm{F}$ and $\mathrm{NF}$ groups $(P=0.0087)$, the other differences were not significant $(\mathrm{P}>$ 0.13). When water was present the differences disappeared and the three groups no longer differed (ANOVA, $P=0.7282$ ). This change was mainly due to the increase of the number of animals not entering inside the corridor. This increase affected the groups in a similar manner (two to three animals /6 in each group). 


\section{Discussion}

We hypothesized that adding water in the corridor will constitute an obstacle for the mice. In both sexes the latency to enter into the corridor increased between the two stages, and mice made numerous attempts before entering the corridor only when it was filled with water. The number of mice crossing the corridor decreased from the familiarization to the experimental stage. However, water filling did not constitute the only difference between the two stages. In the experimental stage, mice had already experienced the device in the preceding stage. This first stage may have reduced the motivation of the mice to explore once again the device. Actually, males reduced the time spent inside the corridor when it was filled with water; nevertheless, this reduction seems to have been more easily explained by the unpleasant aspect of locomotion in water than by a decrease in motivation. In females, the situation was different. Once a female had entered in the corridor filled with water, she tended to behave in a similar manner as during the familiarization stage. The females remained in the corridor for a relatively long period (circa two minutes). For females, the difficulty was to enter into the water rather than to stay in it. As a consequence, we concluded that water was an obstacle to the mice in our paradigm, and our results agree with those of Sherwin in laboratory mice [27].

The aim of our protocol was to evaluate the motivation of the subject individual to cross an obstacle in order to reach the target individual. We hypothesized the social motivation of mice to differ according to their degree of familiarity with the target individuals. According to preceding experiments [28, 29], we expected that both males and females would display greater social motivation to join a familiar than an unfamiliar target animal. Actually, our results revealed unexpected differences between males and females.

In males, the three experimental groups did not differ during the familiarization phase but were differentiated during the experimental phase: the obstacle (i.e. water) clearly revealed differences of social motivation between the subjects. The subjects of the NF group behaved in a different manner compared to the others. Only one male entered into the corridor, and the number of attempts was the highest of the three groups. Amazingly, subjects from the $\mathrm{S}$ group were the fastest to enter into the corridor filled with water and displayed fewer attempts before they dived into the water. The males 
from the $\mathrm{F}$ group behaved in a similar manner. Males did not seem to be more motivated to join a familiar individual than to explore the device itself. Discrimination between groups was characterized more by avoiding an unknown conspecific rather than by reaching a familiar individual.

The three experimental groups of females already differed during the familiarization phase. The subjects of the F group entered the corridor more rapidly than the female subjects of the

NF group, the $\mathrm{S}$ group was intermediate. We have no clear explanation for these differences. It is unlikely that the female subjects perceived the nature of the target female before entering the ending box. As a consequence, females of the three groups should not differ in their motivation to explore and to reach the ending box. Moreover, if the differences observed during the familiarization period were linked to the nature of the target females, then one might have expected that in the experimental stage, this difference should at least remain at the same level or should have increased. This was not the case. The difference of motivation to explore or to reach the target female did not withstand the obstacle of water. During the experimental stage, most females refused to enter the water, and those who entered seemed to have no problem staying in the water. They explored the corridor as much as during the familiarization phase. Our conclusion is that, in both stages, females were more interested in the exploration of the device than in the nature and in the presence of a target female in the ending box.

This test was based on the idea that the strength of a social bond could be evaluated by the cost an individual was ready to pay in order to gain access to a conspecific. Our results revealed a difference between sexes, whereas we predicted that mice of both sexes should be ready to pay more to gain access to a familiar than to an unfamiliar conspecific. According to our hypothesis, males were more ready to pay for gaining access to familiar males, and avoided unfamiliar males. In females, despite what may be assumed when tested without the obstacle (water), social bond was not stronger in familiar than in unfamiliar females. Females were not ready to pay for their access to another female, even a familiar one

These differences between the sexes may be interpreted if we consider the social organisation of this species. In this monogamous species, associations between adult females are scarce and have been described in the field, mainly when there is a shortage of males [35-37]. According to Komers and Brotherton [38], mammal females of monogamous species tend to disperse more in order to 
monopolize sufficient resources to succeed in their reproduction. Contrary to the polygynous house mouse, mound-building mouse females display a very low level of tolerance which prevents female associations [29]. Association between females, even during reproduction seems to be possible only between familiar females, and even in this case, their reproductive success is impaired by polygyny [39]. Adult males present a low level of tolerance between unfamiliar individuals [29], but, contrary to house mouse males, never develop a hierarchy. In our breeding stock, males from a same litter can be maintained together over a period exceeding six months with no aggression observed. Spatial associations between males, moreover, have been described in the field [36]. The results of the present experiment tended to confirm these behavioural and field data. Our study showed that, although male and female mound-building mice were able to display a high level of tolerance between familiar individuals as observed in over-wintering groups [28], they did not develop a strong social attraction between each other. Moreover, our experimental paradigm suggested strongly that, at least in Mus spicilegus, strong social bonds are not necessary to the development of a high level of tolerance between individuals.

\section{References}

[1] K. Broad, J. Curley, E. Keverne, Mother-infant bonding and the evolution of mammalian social relationships, Philos. Trans. R. Soc.B: Biol. Sci. 361 (1476) (2006) 2199-2214.

[2] N. Sachser, Of domestic and wild Guinea pigs: Studies in sociophysiology, domestication, and social evolution. Naturwissenschaften 85(7) (1998) 307-317.

[3] D. Cubicciotti III, W.A. Mason, Comparative studies of social behavior in Callicebus and Saimiri: male-female emotional attachments. Behav. Biol. 16(2) (1976) 185-197.

[4] A.C. DeVries, M. B. DeVries, S. Taymans, C. S. Carter, Modulation of pair bonding in female prairie voles (Microtus ochrogaster) by corticosterone. Proc. Ntl Acad. Sci. USA 92 (1995) 7744-7748.

[5] L.J. Young, M. M. Lim, B. Gingrich, T. R. Insel, Cellular mechanisms of social attachment. Horm. Behav. 40(2) (2001) 133-138.

[6] C.S. Carter, Neuroendocrine perspective on social attachment and love. Psychoneuroendocrinology 23(8) (1998) 779-818.

[7] R.C. Fraley, C.C. Brumbaugh, M.J. Marks, The evolution and function of adult attachment: a comparative and phylogenetic analysis. Journal of Personality and Social Psychology 89(5) (2005) 731-46. 
[8] J.K. Rilling, J. T. Winslow, D. O' Brien, D. A. Gutman, J. M. Hoffman, C. D. Kilts, Neural correlates of maternal separation in rhesus monkeys. Biol. Psychiatry 49(2) (2001) 146-157.

[9] R.E. Shepherd, J.A. French, Comparative analysis of sociality in lion tamarins (Leontopithecus rosalia) and marmosets (Callithrix kuhli): responses to separation from long-term pairmates. J. Comp. Psychol. 113(1) (1999) 24-32.

[10] M.B. Hennessy, J. Weinberg, Adrenocortical activity during conditions of brief social separation in preweaning rats. Behav. Neural Biol. 54(1) (1990) 42-55.

[11] L.B. Martin II, et al., Prolonged separation delays wound healing in monogamous California mice, Peromyscus californicus, but not in polygynous white-footed mice, $P$. leucopus. Physiol. Behav. 87(5) (2006) 837-841.

[12] F.C. Flower, D.M. Weary, Effects of early separation on the dairy cow and calf: 2. Separation at 1 day and 2 weeks after birth. App. Anim. Behav. Sci. 70(4) (2001) 275 284.

[13] T.F. Pettijohn, Attachment and separation distress in the infant guinea pig. Dev. Psychobiol. 12 (1979) 73-81.

[14] C.A. Hendrie, N.J. Starkey, Pair-bond disruption in Mongolian gerbils: effects on subsequent social behaviour. Physiol. Behav. 63(5) (1998) 895-901.

[15] N.J. Starkey, C.A. Hendrie, Disruption of pairs produces pair-bond disruption in male but not female Mongolian gerbils. Physiol. Behav. $65(3$ (1998) 497-503.

[16] A. Boissy, P. Le Neindre, Behavioral, cardiac and cortisol responses to brief peer separation and reunion in cattle. Physiol. Behav. 61(5) (1997) 693-699.

[17] G. Byrne, S.J. Suomi, Social separation in infant Cebus apella: patterns of behavioral and cortisol response. Int. J. Dev. Neurosci. 17(3) (1999) 265-274.

[18] M. L. Terranova, F. Cirulli, G. Laviola, Behavioral and hormonal effects of partner familiarity in periadolescent rat pairs upon novelty exposure. Psychoneuroendocrinology 24(6) (1999) 639-656.

[19] F. Cirulli, M.L. Terranova, G. Laviola, Affiliation in periadolescent rats: Behavioral and corticosterone response to social reunion with familiar or unfamiliar partners. Pharmacol. Biochem. Behav. 54(1) (1996) 99-105.

[20] K.J. Parker, T.M. Lee, Female meadow voles (Microtus pennsylvanicus) demonstrate same-sex partner preferences. J. Comp. Psychol. 117(3) (2003) 283-289.

[21] J.R. Williams, K.C. Catania, C.S. Carter, Development of partner preferences in female prairie voles (Microtus ochrogaster): The role of social and sexual experience. Horm. Behav. 26(3) (1992) 339-349.

[22] X. Boivin, R. Nowak, A. T. Garcia, The presence of the dam affects the efficiency of gentling and feeding on the early establishment of the stockperson-lamb relationship. App. Anim. Behav. Sci. 72(2) (2001) 89-103.

[23] G. Faerevik, M.B. Jensen, K.E. Boe, Dairy calves social preferences and the significance of a companion animal during separation from the group. App. Anim. Behav. Sci. 99(3-4) (2006) 205-221.

[24] M.S. Dawkins, Battery hens name their price: Consumer demand theory and the measurement of ethological 'needs'. Anim. Behav. 31(4) (1983) 1195-1205.

[25] M.C. Appleby, Life in a variable world: Behaviour, welfare and environmental design. App. Anim. Behav. Sci. 54(1) (1997) 1-19.

[26] D.M. Broom, The scientific assessment of animal welfare. App. Anim. Behav. Sci. 20(1-2) (1988) 5-19.

[27] C.M. Sherwin, Laboratory mice persist in gaining access to resources: a method of assessing the importance of environmental features. App. Anim. Behav. Sci. 48(3-4) (1996) 203-213. 
[28] P. Gouat, C. Féron, S. Demouron, Seasonal reproduction and delayed sexual maturity in mound-building mice Mus spicilegus. Reprod., Fertil. Dev. 15(3) (2003) 187-195.

[29] B. Patris, P. Gouat, C. Jacquot, N. Christophe, C. Baudoin, Agonistic and sociable behaviors in the mound-building mice, Mus spicilegus: a comparative study with Mus musculus domesticus. Aggressive Behav. 28(1) (2002) 75-84.

[30] P. Gouat, B. Patris, C. Lalande, Conspecific and heterospecific behavioural discrimination of individual odours by mound-building mice. C. R. Acad. Sci., Ser III 321 (1998) 571-575.

[31] S. Maslak, P. Gouat, Short-term contact elicits heterospecific behavioral discrimination of individual odors in mound-building mice Mus spicilegus. J. Comp. Psychol. 116(4) (2002) 357-362.

[32] D. Colombelli-Négrel, P. Gouat, Male and female mound-building mice, Mus spicilegus, discriminate dietary and individual odours of conspecifics. Anim. Behav. 72(3) (2006) 577-583.

[33] R. Mundry, J. Fischer, Use of statistical programs for nonparametric tests of small samples often leads to incorrect $P$ values: examples from Animal Behaviour. Anim. Behav. 56(1) (1998) 256-259.

[34] S. Holm, A simple sequentially rejective multiple test procedure. Scandinavian J. Statist. 6 (1979) 65-70.

[35] P. Gouat, K. Katona, C. Poteaux, Is the socio-spatial distribution of mound-building mice, Mus spicilegus, compatible with a monogamous mating system? Mammalia 67(1) (2003) 15-24.

[36] D. Simeonovska-Nikolova, Spatial organization of the mound-building mouse Mus spicilegus in the region of northern Bulgaria. Acta zool. Sin. 53(1) (2007) 22-28.

[37] D. Simeonovska-Nikolova, S. Gerasimov, Seasonal changes of some population characteristics of Mus spicilegus Petenyi in North Bulgaria. Acta Zool. Bulg. 52(2) (2000) 81-90.

[38] P.E. Komers, P.N.M. Brotherton, Female space use is the best predictor of monogamy in mammals. Proc. R. Soc. Lond., Ser. B 264 (1997) 1261-1270.

[39] P. Gouat, C. Féron, Deficit in reproduction in polygynously mated females of the monogamous mound-building mouse Mus spicilegus. Reprod., Fertil. Dev. 17(6) (2005) 617-623. 
S E
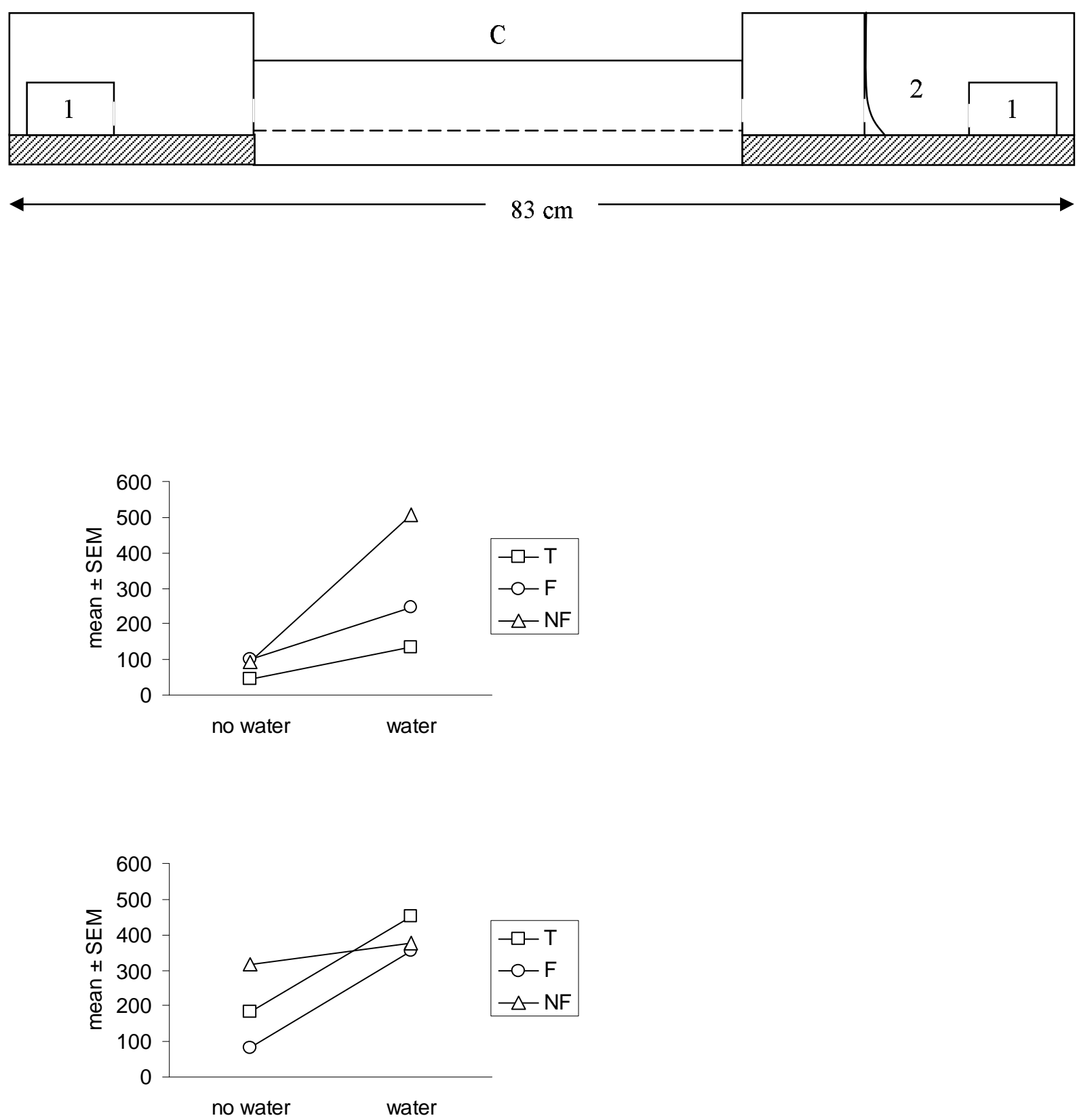
Fig. 1: experimental device:

S: starting-box ; C: corridor ; E: ending-box ; 1: shelter box ; 2: one-way door.

Fig. 2: latency of the first entrance in the corridor, in males.

Fig. 3: latency of the first entrance in the corridor, in females. 